Mariola Wokk

DOI: 10.33896/PorJ.2019.9.4

(Uniwersytet Warmińsko-Mazurski, Olsztyn,

e-mail: mariola.wolk@uwm.edu.pl)

\title{
INNY, RÓŻNY, ODRĘBNY, ODMIENNY. PRÓBA WYODRĘBNIENIA JEDNOSTEK JĘZYKA
}

1. Problem 'inności' i pojęć pokrewnych, takich jak np. 'różność', 'odmienność' czy 'odrębność', w ujęciu językoznawczym został do tej pory opisany - według moich ustalen - wybiórczo i niekompleksowo. Przymiotnik inny został zauważony przez Annę Wierzbicką i włączony na listę indefinibiliów, czyli wyrażeń powszechnie zrozumiałych, uniwersalnych i niedefiniowalnych [por. Wierzbicka 1996, polski przekład Wierzbicka 2006, 155-156]. Uwagi na temat przymiotnika różny zostały sformułowane przez Macieja Grochowskiego w jego tekście poświęconym jednostce najróżniejsze na tle problemów stopniowania przymiotników [por. Grochowski 2015]. Pojedynczych, raczej zdawkowych i nie zawsze bezpośrednio podanych, za to inspirujacych, uwag na temat wziętych do zbadania jednostek doszukać się można w innych pracach M. Grochowskiego poświęconych problemom ograniczeń w stopniowaniu przymiotników [por. Grochowski 2016; 2017; 2018]. Wszystkie brane pod uwagę wyrażenia zostały oczywiście zdefiniowane w słownikach współczesnej polszczyzny, choć ze względu na przede wszystkim użytkowy charakter tego rodzaju prac trudno oczekiwać od ich autorów rozwiąań rozstrzygajacych istotne problemy związane $z$ opisem określonych pojęć. Definicję słów odmienne, różne (potraktowanych jako semantycznie tożsame odpowiedniki łac. diversa) można odnaleźć w inspirujących Tablicach definicji G.W. Leibniza ${ }^{1}$ [por. polski przekład pod red. E. Janus, 1975, 39]. ${ }^{2}$

1 Por. eadem - takie same - 'takie, które moga być zamiast siebie podstawione przy zachowaniu prawdziwości', diversa-odmienne, różne - 'które inaczej' [Leibniz 1975, 39].

${ }^{2}$ Można się spodziewać, że w ustaleniach filozofów poruszających w swych pracach problemy, które - niekoniecznie bezpośrednio - wiążą się z podjętym tu zagadnieniem 'inności', dałoby się odnaleźć inspirujące wątki. W tym miejscu, na etapie jedynie wstępnego oglądu interesującego mnie tematu, nie podejmuję się jednak rozwinięcia tej myśli (niewykluczone, że warto byłoby poświęcić jej odrębne rozważania). 
Niniejsza analiza również nie pretenduje do roli kompletnej. Zamierzam jednak wybrane do zbadania zagadnienia potraktować szczegółowo. Przedmiotem opisu będą wyrażenia inny, różny, odrębny, odmienny, a ściślej: jednostki językowe, których głównym (a nieraz jedynym) składnikiem jest któreś $z$ wymienionych wyrażeń, nie można bowiem a priori zakładać, że mamy do czynienia $z$ ciagami jednosegmentowymi, podobnie jak nie można być pewnym ich kształtu (także pod względem fleksyjnym), dopóki nie zweryfikuje się go w systematycznych badaniach. Ustalenie postaci jednostek jezzyka (w rozumieniu Andrzeja Bogusławskiego [por. Bogusławski 1976]) będzie stanowiło centralny przedmiot tych obserwacji. Po wynikach takich badań można się spodziewać nie tylko zdania sprawy $z$ liczby odrębnych bytów językowych, lecz także z syntaktycznych właściwości analizowanych wyrażeń. Te zaś moga stanowić istotne przesłanki wniosków stricte semantycznych. Wprawdzie systematyczna analiza znaczenia wymaga tyle uwagi i miejsca, że nie sposób podjąć się jej w ramach tego stosunkowo niedługiego tekstu, ale próba wyodrębnienia spośród wielu różnych ciągów jednostek języka może odsłonić podstawę mechanizmu orzekania rozpatrywanych właściwości. Dokonanie ustaleń, o których mowa, polega na wyodrębnieniu określonego bytu językowego $z$ potoku żywej mowy, dlatego każdorazowo należy wyjść od przywołania autentycznych kontekstów zawierających wymienione wyżej wyrażenia. Największą różnorodność daje się zaobserwować w obrębie wystapień tekstowych słowa inny, pod tym względem wyróżnia się też przymiotnik różny, dlatego wymagać one będą więcej uwagi niż dwa pozostałe przymiotniki: odmienny i odrębny. W trosce o porządek i szczegółowość opisu każde $z$ wyrażeń zostanie potraktowane $z$ osobna.

2. Zanim przejdę do szczegółowego rozpatrzenia każdego wziętego do zbadania wyrażenia, przyjrzę się ich charakterystykom słownikowym pod katem liczby zarejestrowanych jednostek czy też częściej - znaczeń. W zasadzie leksykografowie zgodnie postulują ich wielość, a przyporząkowane wyodrębnionym wyrażeniom opisy znaczenia i konteksty ilustrujace ich użycie pokazuja podobieństwo przyjętych w słownikach rozwiazań.

Wyrażeniu inny przypisuje się w słownikach dwa znaczenia i - co ciekawe - różniące się między sobą ujęcia klasyfikujące słowo inny do części mowy. W pierwszym haśle słownikowym inny klasyfikowane jest jako przymiotnik [SWJP], zaimek przymiotny wskazujacy [ISJP] lub nieokreślony [SJPSz, USJP] i definiowane najczęściej jako 'nie ten / taki sam'. W drugim inny klasyfikuje się albo jako przymiotnik w użyciu rzeczownikowym [SJPSz, USJP], albo jako zaimek przymiotny wskazujący, który może być używany jako rzeczownik [ISJP], albo też jako rzeczownik o odmianie przymiotnikowej [SWJP, PSWP], i definiuje $z$ grubsza rzecz biorac jako 'inną osobę', w ISJP - słusznie - szerzej: 'inna osoba, rzecz, sytuacja' itp. 
Różny gramatycznie sklasyfikowany został jednolicie jako przymiotnik, któremu przypisuje się w SJPSz i SWJP dwa, a w ISJP i USJP - w zasadzie trzy znaczenia (czwarte w ISJP dotyczy jednostki ktoś wymyśla komuś od różnych reprezentującej inne pojęcie niż tu analizowane). Zasadniczo oddziela się różny w znaczeniu ujmowanym najogólniej jako 'nie taki sam jak coś / ktoś' i różny w znaczeniu zbliżonym do 'rozmaity'; drugie $z$ nich trafnie definiuje SWJP: 'taki, który skupia wiele elementów o odmiennych kształtach, barwach, wartościach' [SWJP, 982]. W ISJP i USJP wyodrębnione zostało dodatkowo (jako zaimek przymiotny wskazujący) potoczne wyrażenie różne (różni) nazywające takie osoby lub sprawy, 'których bliżej nie znamy lub nie chcemy określać' [ISJP II, 516, por. USJP III, $1084-$ ' $z$ niechęcia o wielu bliżej nieznanych osobach'], w odniesieniu do ludzi używane jako rzeczownik (np. Różni u nas nocuja). ${ }^{3}$ Pisząc o charakterystykach słowa różne w ISJP, nie sposób pominać milczeniem sposobu jego zdefiniowania, zwłaszcza w podstawowych dwóch znaczeniach czy też, antycypując: znaczeniach odpowiadajacych dwóm jednostkom: '1. jeśli jakieś rzeczy lub osoby sa różne, to nie sa takie same, lecz różnią się między sobą. Mówimy też, że jedna rzecz jest różna od drugiej; ${ }^{4} 2$. słowa różny używamy, aby zaznaczyć, że mówimy o rzeczach odrębnych i różniących się między sobą' [ISJP II, 516]. Przytoczone objaśnienia zawieraja błędy: idem per idem ${ }^{5}$ - definiensem wyrażenia różny są bowiem słowa różnić się, różniący się, oraz ignotum per ignotum, ponieważ różny definiuje się za pomocą bardziej złożonego semantycznie wyrażenia odrębny. Poza tym w pierwszym $z$ opisów dodatkowo doszło do powstania sformułowania redundantnego (nie sa takie same, lecz różnia się, podobnie jest w PSWP XIV, 266). Wskazane niedostatki w definiowaniu przyczyniaja się do najpoważniejszej w moim odczuciu wady rozpatrywanych charakterystyk, mianowicie do rozmycia różnicy semantycznej pomiędzy dwiema słusznie wyodrębnionymi jednostkami. Pod tym względem lepiej wypadaja definicje $z$ pozostałych uwzględnionych w tym przeglądzie słowników.

W charakterystyce słowa odmienny, zgodnie uznanego przez leksykografów za przymiotnik, wyodrębnia się zasadniczo dwa znaczenia, ${ }^{6}$ przy

${ }^{3}$ Wydaje się, że jest ono bliskie, zwłaszcza ze względu na właściwości pragmatyczne, pewnym potocznym użyciom słowa inny: Pisali o tym Żeromski, Reymont $i$ inne Konopnickie.

4 Zaskakuje umieszczenie wśród przykładów ilustrujących to znaczenie zdania $z$ wyrażeniem różny od zera [ISJP II, 516]. Jest to bowiem inna jednostka językowa, o czym świadczy niewymienność jej składników.

5 Zwraca na to uwagę również $\mathrm{M}$. Grochowski w swoim tekście o jednostce najróżniejsze [por. Grochowski 2015, 52].

6 W SJPSz, USJP i PSWP odnotowane zostało także przestarzałe użycie tego wyrażenia (co ciekawe, jedynie w SJPSz pragmatycznie scharakteryzowane właśnie jako przestarzałe), ilustrowane m.in. przez wyrażenie odmienne koleje losu [SJPSz II, 462; USJP II, 1152; PSWP XXV, 374]. 
czym to drugie odnosi się do specjalistycznie charakteryzowanej właściwości wyrażeń językowych (wyrazy odmienne), jest więc terminem. W obrębie wyrażeń języka ogólnego należałoby więc mówić o jednej jednostce odmienny i jednym odpowiadającym jej znaczeniu, które przybliża się za pomoca prostszego semantycznie pojęcia różnicy [por. np. SWJP, 658: 'mający cechę różniąca go całkowicie od innych; przeciwstawny'; USJP II, 1152: 'nie taki sam, różniacy się całkowicie od kogoś lub czegoś; inny, różny'; PSWP XXV, 374: ‘taki, który różni się od innych']. Znów zastanawia rozwiąanie przyjęte w ISJP, w którym inny w znaczeniu 1. (tj. nieterminologicznym, por. ISJP I, 1113: 'jeśli coś jest odmienne od czegoś, to się od tego różni') uznaje się za synonim odmiennego, ale takiej adnotacji brakuje w haśle odmienny (choć jasne jest, że relacja ma charakter obustronny), również definicje obu wyrażeń w mających im odpowiadać znaczeniach nie sa identyczne [por. ISJP I, 538; ISJP I, 1113].

Wyrażenie odrębny - sklasyfikowane gramatycznie jako przymiotnik - uznane zostało w ISJP, SWJP, USJP i PSWP za wieloznaczne, w SJPSz zaś charakteryzuje się je monosemicznie jako 'odmienny od innych, niepodobny do innych' [SJPSz II, 472], przy czym w ISJP i SWJP złożony semantycznie predykat odmienny zastępuje prostsze pod tym względem wyrażenie różny (ISJP I, 1123: 'odrębne rzeczy, zjawiska lub osoby są bardzo różne i niezależne od siebie'), w PSWP czasownik różnić się (w USJP imiesłów różniacy), ale treść wszystkich definicji zmierza w takim samym kierunku. Drugie $z$ wyodrębnionych w pozostałych słownikach znaczeń objaśnia się jako 'to, co jest wydzielone spośród innych rzeczy' [ISJP I, 1123], 'będący samodzielną całością' [SWJP, 664; por. USJP II, 1171; PSWP XXV, 436].

Jak widać, charakterystyki słownikowe przynoszą pewne uporządkowanie wielości i różnorodności bytów językowych zorganizowanych wokół interesujących mnie wyrażeń. Czas na wyłowienie ich $z$ potoku żywej mowy, a więc przytoczenie autentycznych kontekstów, w których występuja, wytyczenie granic między nimi, ustalenie statusu rozpatrywanych ciagów i zweryfikowanie niektórych rozwiązań leksykograficznych.

3. Uważne prześledzenie wystapień tekstowych wyrażenia inny odkrywa ich dość duże zróżnicowanie. Główny problem sprowadza się $\mathrm{w}$ tym wypadku do ustalenia statusu wyrażeń $z$ tym słowem, a więc do rozstrzygnięcia, czy za każdym razem mamy do czynienia $z$ jednostka języka, czy też może $z$ regularnym złożeniem wyrażeń, oraz do wskazania liczby jednostek językowych $z$ segmentem inny. Oto przykładowe autentyczne (wzięte $z$ NKJP) konteksty $z$ tym wyrażeniem:

(1) Każdy ma inny kamień i rzucaja $w$ siebie tymi kamieniami.

(2) Taki sam uśmiech jak u Sophie, lecz inny kolor włosów.

(3) Tutaj było inne powietrze, niebo, ziemia.

(4) Teraz sa inne kryteria.

(5) Potrzeby Tomka sa inne niż twoje. 
(6) We Włoszech zapanowała zatem atmosfera wzajemnego pocieszania sie, ale $w$ Polsce nastroje sa inne.

(7) Suzanne! Ja jestem zupełnie inny, niż pani sobie wyobraża.

(8) Mężczyzna musi być zupetnie inny niż kobieta.

(9) Jeden miał zła matke, inny guza na mózgu.

(10) Pan to $w$ ogóle cały dzień tylko by spat - dodaje inny.

(11) Wyobraź sobie lekarza, który widzi, że inny lekarz aplikuje choremu fatszywe lekarstwo.

(12) Ktoś poit ich herbata z termosu, inny okrywał kocem.

(13) Widzę tylko jedna rusałke. Gdzie sa inne?

(14) Przejście przez brame obozowa mogło spowodować śmierć, bicie $i$ inne kary stosowane wobec więźniów.

(15) Próbowat jej wytłumaczyć, że pociag do jednej kobiety bynajmniej nie oznacza, że inna została odrzucona jako gorsza czy brzydsza.

Podstawowa różnica daje się zauważyć między przykładami (1)-(8) a przykładami (9)-(15). Sprowadza się ona do funkcji, jaka pełni w tych zdaniach badane wyrażenie. W pierwszych ośmiu przykładach występuje słowo inny implikujace istnienie jakiegoś drugiego elementu, z którym wskazany uczestniczy w mechanizmie porównania ze względu na jakąs cechę. W zdaniach (5), (7), (8) jest on realizowany powierzchniowo $\mathrm{w}$ układzie $z$ przyimkiem niż, por. np.: potrzeby inne niż twoje, inny, niż ktoś sobie wyobraża, mężczyzna jest inny niż kobieta, choć może też występować w ramie z przyimkiem od, por.: Mój kluczyk jest inny od twego, Ten utwór był troche inny od pozostałych naszych piosenek. Wprawdzie w kolejnych przykładach, tj. (9)-(15), również wchodzi w grę odesłanie do innego elementu, ale już nie ze względu na cechę stanowiąca podstawę porównania, dlatego wyłącznie „na upartego” inny daje się wstawić $\mathrm{w}$ ramę $z$ którymś $z$ przywołanych przyimków, por. nieempiryczne: Jeden miał zła matkę, ?inny od niego miał guza na mózgu, Pan to w ogóle cały dzien tylko by spat - dodaje inny niż on, Widzę tylko jedna rusałkę. Gdzie sa ? inne niż ta? Nie jest to jednak argument najistotniejszy. Do tego, że w wyodrębnionych dwóch grupach przykładów mamy do czynienia $z$ dwoma różnymi bytami językowymi, przekonuje test $z$ maksymalizatorem zupełnie. W dwóch przykładach z grupy (1)-(8), mianowicie (7) i (8), operator ten pojawił się autentycznie przy rozpatrywanym wyrażeniu, do pozostałych sześciu kontekstów można go bez problemu dostawić, por. akceptowalne połaczenia: zupełnie inny kamień, zupełnie inny kolor włosów, zupetnie inne powietrze, zupetnie inne kryteria, zupetnie inne potrzeby, zupelnie inne nastroje. W odróżnieniu od nich testu $\mathrm{z}$ zupetnie nie przechodza pomyślnie zdania z grupy (9)-(15), por. nieakceptowalne: Jeden miał zła matkę, *zupełnie inny guza na mózgu, Pan to w ogóle cały dzień tylko by spał - dodaje *zupełnie inny... itd. Taka różnica wynika $z$ tego, że operator zupełnie - jako wykładnik stopnia cechy - może być sensownie użyty przy wyrażeniu, za pomoca którego orzeka się jakąś cechę, dostawienie go do wyrażenia apredykatywnego grozi więc dewia- 
cja, por.: *zupelnie ten, *zupełnie tamten, *zupełnie poszczególne, *zupetnie jakiś, "zupełnie każdy. Funkcja słowa inny w zdaniach (1)-(8) polega właśnie na przypisywaniu czemuś jakiejś właściwości, dlatego dopuszcza ono uzupełnienie w postaci operatora zupetnie. W zdaniach (9)-(15) wyrażenie inny służy do wskazywania, identyfikowania czy różnicowania pewnych obiektów. W pierwszej grupie przykładów mamy zatem wyrażenie predykatywne, w drugiej - referencjalne. ${ }^{7}$ Różnicę między nimi dałoby sie na potrzeby tej charakterystyki (jest to bowiem - zgodnie $z$ propozycja Wierzbickiej [1996] - wyrażenie niedefiniowalne) przybliżyć następująco: inny $_{\text {pred }}$ : 'nie taki jak p (ze względu na q)' vs inny ${ }_{\text {refer }}$ : 'nie ten, o którym mowa'. Mechanizm orzekania cechy bycia innym, opierajacy się na porównaniu $z$ jakimś (co najmniej jednym) innym elementem, powinien być widoczny w pełnym zapisie postaci jednostki językowej z przykładów (1)-(8), czyli: inny niż w opozycji do zapisu inny odnoszącego się do kształtu jednostki językowej reprezentowanej w zdaniach (9)-(15).

Ustalenia wymaga jeszcze m.in. kwestia statusu wyrażenia ktoś inny, któremu bliżej do jednostki inny pełniącej funkcję referencjalną (w opisach słownikowych traktuje się te dwa wyrażenia jako tożsame) aniżeli do predykatywnego wyrażenia inny niż. W kontekstach $z$ pierwsza $z$ nich, w których odsyła ona do osoby, o ile nie ma w jej bezpośrednim sąsiedztwie określanego rzeczownika (jak w przykładzie (11)), można dostawić do niej zaimek nieokreślony ktoś, por. np. Jeden miał zła matkę, ktoś inny guza na mózgu, Pan to $w$ ogóle cały dzień tylko by spał - dodaje ktoś inny, Ktoś poił ich herbata z termosu, ktoś inny okrywał kocem. W pozostałych przywołanych wyżej przykładach (tj. (13)-(15)) w pozycji lewostronnej musiałby się pojawić inny zaimek nieokreślony niż ktoś, np. jakiś, por.: Widzę tylko jedna rusałkę. Gdzie sa jakieś inne? W niektórych kontekstach słowo inny, pozbawione lewostronnego uzupełnienia, pełni funkcję członu nominalnego (na co konsekwentnie zwracaja uwage autorzy charakterystyk słownikowych), wówczas w sposób naturalny dopuszcza ono uzupełnienie go rozpatrywanym zaimkiem, por.: Ona wolała innego - Ona wolała kogoś innego. Taka operacja nie jest oczywista w wypadku użycia tego wyrażenia w liczbie mnogiej w branej pod uwagę funkcji, np. Zajma się tym inni-Zajma sie tym ?jacyś inni. Zastanawiajacy rezultat takiego uzupełnienia wiąże się $z$ referencją wyrażenia inni: jeśli jest ona określona, dostawienie zaimka jacyś / jakieś może nie współgrać $z$ intencja nadawcy, wówczas bardziej adekwatne byłoby mówienie

7 Zuzanna Topolińska charakteryzuje je jako leksykalny wykładnik zbiorowościowego charakteru referenta, a ściślej: dwuelementowej koniunkcji argumentów, którym przypisuje się różne predykaty. Inny jest zatem wariantywnym członem następujacych opozycji: jeden : drugi / inny, jedni : drudzy / inni, jedne : inne (drugie) [por. Topolińska 1983, 321]. Inni to według $Z$. Topolińskiej „inni przedstawiciele zbiorowości = zbiorowość X-ów minus jej podzbiór $\mathrm{x}_{1}$ ” [Topolińska 1983, 322]. 
o tych innych (Zajma sie tym ci inni) lub nieuzupełnianie tego wyrażenia. Niemniej lewostronna pozycja przy wyrażeniu inny może być wypełniana także przez inne zaimki niż ktoś, por. jakiś inny, coś innego, nikt inny, żaden inny. $Z$ pewnością więc nie mamy tu do czynienia $z$ jednostka języka o postaci ktoś inny, lecz z jednostka operacyjna o postaci_inny, podlegająca regularnemu przekształceniu, w wyniku którego określony element jest zastępowany innym elementem [por. Bogusławski, Wawrzyńczyk 1993, 16], a forma fleksyjna wyjściowego leksemu inny bywa pod wpływem takich substytucji dostosowywana pod względem liczby i rodzaju do jego lewostronnego uzupełnienia (np. coś innego). O zasadności odróżnienia jednostki _inny od inny z przykładów (9)-(15) świadczy to, że choć w wielu kontekstach do wyrażenia inny można dostawić rozpatrywany zaimek nieokreślony, to operacja taka w odwrotnym kierunku nie zawsze jest możliwa. Bywa, że próba usunięcia lewostronnego elementu ktoś (w układzie ktoś inny) daje wyrażenia nieakceptowalne, ${ }^{9}$ por.: Zrobił to ktoś inny vs *Zrobił to inny, Ktoś inny wysyła te świnstwa vs *Inny wysyła te świnstwa, Odnajdzie ja ktoś inny vs *Odnajdzie ja inny. Źródłem dewiacji jest w tym wypadku niespełnienie wymagań składniowych czasownika, zgodnie $z$ którymi powinna pojawić się przy nim fraza nominalna, np. Zrobił to inny mężczyzna, mogąca podlegać redukcji do członu określanego (Zrobił to mężczyzna), ale nie określającego ("Zrobił to inny). ${ }^{10}$ Takie operacje powoduja $z$ kolei zmianę zasadniczą o tyle, że jednostka _inny występująca w funkcji referencjalnej zaczyna zbliżać się do jednostki inny niż $\dot{z}_{-}$pełniącej funkcje predykatywną. Poza tymi wymaganiami zdaje się natomiast funkcjonować najwyraźniej znominalizowana postać wyrażenia w liczbie mnogiej: inni (co ciekawe, zdecydowanie rzadziej inne), zwykle pozbawiona określeń referencjalnych, por. np.: Załatwia to inni, Zostawmy te robote innym itp.

Ostatnia rzeczą wymagająca $\mathrm{w}$ tym miejscu rozstrzygnięcia jest status ciagów w rodzaju ten czy inny, taki czy inny pojawiajacych się np. we

8 Z. Topolińska opisuje wyrażenie jakiś inny jako złożony operator czy też operator "wyższego piętra” operujacy na grupach tworzacych łącznie $z$ operatorami referencji podstawowej nowe operatory złożone. Funkcja dodatkowych elementów sprowadza się do potwierdzenia zakresu odniesienia odpowiednich grup imiennych. Element inny, występujacy samodzielnie lub w postpozycji wobec operatora typu jakiś, służy identyfikacji (negacji identyfikacji) [por. Topolińska 1983, 372-373].

9 Rozpatrywane przykłady da się zaakceptować, jeśli potraktuje się je jako eliptyczne sekwencje osadzone w określonym kontekście słowno-sytuacyjnym.

10 Przed takimi rezultatami brane pod uwage wcześniej przykłady chroni kontekst. Wyrażenie inny funkcjonuje w nich na zasadzie anafory (lub - zgodnie $z$ ustaleniem $Z$. Topolińskiej - jest jednym $z$ członów dwuelementowego wyrażenia, por. przypis 7.), jest bowiem skorelowane $z$ wcześniejszym określeniem, mającym postać grupy nominalnej, np. Ktoś poił ich herbata $z$ termosu, inny okrywat kocem. 
frazach: ten czy inny obywatel / telefon / fizyk, taki czy inny wybór / / grzech / kontrakt / samochód. W zasadzie wszystkie elementy tych wyrażeń podlegaja substytucji, np. ten czy tamten, taki czy owaki, ten lub inny, taki lub owaki, należy zatem uznać je za regularne złożenia, a nie niepodzielne jednostki języka. Bezdyskusyjnie zaś za jednostki językowe trzeba uznać rejestrowane w opracowaniach leksykograficznych między innymi czy rzadziej zauważane w słownikach wyrażenia inna sprawa, $\dot{z} e_{-}$czy ktoś ${ }_{i} /$ cośs $_{j}$ jest $z$ innej bajki [por. Bogusławski, Danielewiczowa 2005, 110].

4. Przymiotnik różny wprawdzie nie występuje w tak dużej liczbie ciagów wyrazowych jak inny, ale w obrębie wystapień tekstowych $z$ jego udziałem także daje się zauważyć pewne zróżnicowanie, por. przykładowe konteksty $z$ NKJP:

(16) Ludzie robia różne dziwne rzeczy.

(17) Świat jest przecież różny - i piękny, i brzydki.

(18) Zle aspekty wskazuja na robienie kariery w różny pokrętny sposób.

(19) W tym deszczu to się różne rzeczy moga zdarzyć.

(20) Piękne suknie $w$ różny deseń niech wystroja się na jesień.

(21) To miasto kontrastów, bardzo różne od innych stolic.

(22) Kobiety sa zupetnie różne od mężczyzn - i pod względem fizycznym, i psychicznym.

(23) Poczuł znajomy zapach tortów i ciast, różny od domowego, ale tak samo dawny.

(24) Jeżeli zajac jest różny od żółwia, to lepiej biega.

(25) Poczucie humoru mamy zupełnie różne od rodziców.

W zdaniach $z$ grupy (16)-(20) mamy inna jednostkę językową niż $\mathrm{w}$ zdaniach $z$ grupy (21)-(25). W pierwszej $z$ nich jest nia jednosegmentowy ciag o kształcie - przyjmijmy na razie umownie - różny, w drugiej - wielosegmentowy ciag o postaci różny od_ (ze względu na q). W zdaniach (16)-(20) możliwość pojawienia się przyimka od wraz $z$ wymagana przez niego fraza dopełniaczowa jest zablokowana, ponieważ operacja zestawienia jakiegoś elementu $z$ innym lub innymi, składająca się na właściwość przypisywana za pomoca przymiotnika różny, rozgrywa się w obrębie elementów należących do tej samej kategorii (niewykluczone też, że na zasadzie nieco innej niż w drugiej grupie kontekstów). Inaczej jest w przykładach (21)-(25), w których podobny mechanizm orzekania zasadniczo operuje na porównaniu jednego elementu (np. kobiet $z$ (22)) $z$ innym lub innymi (np. mężczyznami $z$ (22)), należącym/i do innej kategorii. $Z$ tego powodu rozpatrywany element prawostronny, tj. przyimek od i idacy po nim rzeczownik w dopełniaczu, jest obligatoryjny, a jego wyelidowanie prowadzi do powstania konstrukcji albo nieakceptowalnych, por. np. *To miasto kontrastów, bardzo różne, *Jeżeli zając jest różny, to lepiej biega, *Poczul znajomy zapach tortów i ciast, różny, ale tak samo dawny, albo znaczeniowo nietożsamych $z$ wyjściowymi lub niejednoznacznych, np.: Kobiety sa zupetnie różne - i pod względem fi- 
zycznym, i psychicznym (por. z (22)), Poczucie humoru mamy zupetnie różne (por. $z$ (25)). Takiego rezultatu można uniknać w konstrukcjach w rodzaju: Te (dwa) miasta sa różne, Te (dwa) zapachy sa różne, ale tylko wówczas, gdy wyraźnie wyodrębnimy dwa obiekty należące do tej samej kategorii (co również wydaje się możliwe), w takiej sytuacji możemy też pominąć przyimek. ${ }^{11}$ Jego uwzględnienie w zapisie postaci jednostki wydaje się potrzebne o tyle, że zdaje ono explicite sprawę $z$ tego, że w wypadku takiej 'różności', o która tu chodzi (tj. różnej od tej ze zdań (16)-(20)), zawsze w grę wchodzi porównanie dwóch elementów.

W tym miejscu warto wziąć pod uwage postulowany przez M. Grochowskiego kształt jednostki reprezentowanej w tym tekście w zdaniach (16)-(20) (autor nazywa ją umownie atrybutywną w odróżnieniu od tej implikującej prawostronna pozycję $z$ przyimkiem, którą również umownie nazywa orzecznikowa [por. Grochowski 2015, 51]). Ze względu na to, że zasadniczo niemożliwa jest referencja rzeczownika występującego $z$ atrybutem różny do obiektu jednostkowego, autor - podzielając pogląd wyrażony przez A. Bogusławskiego i J. Wawrzyńczyka w drugiej sondzie słownikowej [Bogusławski, Wawrzyńczyk 1993] - wyodrębnia jednostkę majacca postać pluralis, mianowicie różne $X_{i}$ [Grochowski 2015, 52]. Wprawdzie aż trzy z przytoczonych wyżej przykładów - tj. (17), (18) i (20) - zdaja się to ustalenie podważać, ale ich wartość jako możliwych kontrargumentów nie jest chyba wystarczająco mocna. Różny deseń ze zdania (20) jest pod względem akceptowalności dyskusyjny, a forma singularis została prawdopodobnie wymuszona potrzeba rymu, którego nie dałoby się osiagnąc forma pluralis (por. deseń - jesień vs desenie - jesień). Rzeczownik świat ze zdania (17) odnosi się do bytu stanowiącego $\mathrm{w}$ istocie universum istnienia, trudno więc o użycie $\mathrm{w}$ takim wypadku liczby mnogiej, która - choć systemowo przewidywalna - dałaby w istocie zdania o co najmniej dwóch różnych światach, podczas gdy orzekana właściwość rozgrywa się w obrębie jednego, powiedzmy, bytu. Wreszcie zdanie (18) zawiera wyrażenie będące wykładnikiem (raczej mało fortunnym) referencji sposobu i - co istotne - referencji ogólnej, odnosi się więc do wielości sposobów. Lepiej byłoby więc zastapić ją sformułowaniem zawierającym liczbę mnoga badanego przymiotnika, np. na różne sposoby.

11 M. Grochowski przyjmuje, że realizacja argumentu wskazującego na kryterium porównania jest zawsze fakultatywna: „jeżeli [pierwszy argument] jest skwantyfikowany ogólnie (co na płaszczyźnie wyrażenia ujawnia zazwyczaj forma pluralis rzeczownika albo nazwa zbiorowości), realizacja drugiego argumentu jest fakultatywna" [Grochowski 2015, 51]. Trudno jednak uznać zdanie Młodzież szkolna jest różna, ilustrujace te ustalenia, za przekonujące. Nie jest ono bowiem - podobnie jak rozpatrywane wyżej przykłady $z$ wyelidowanym przyimkiem - jednoznaczne. Nie jest jasne, czy elementy różniące występują w obrębie grupy nazwanej młodzieżą, czy też różnica zachodzi pomiędzy młodzieżą a jakąś inna grupa (jak w poprzedzajacym to zdanie w artykule M. Grochowskiego przykładzie: Młodzież szkolna jest pod wieloma względami różna od akademickiej). 
W związku z powyższym przyjmuję rozwiazanie M. Grochowskiego i za właściwa postać jednostki językowej reprezentujacej 'różność' w grupie kontekstów (16)-(20) uznaję ciąg różne (p).

Odmienność i odrębność dwóch omówionych wyżej jednostek języka dodatkowo potwierdza to, w jaki sposób przymiotnik różny reaguje na dostawienie do niego operatorów zupełnie czy całkiem w dwóch rozpatrywanych typach przykładów. W zdaniach (22) i (25) występują autentycznie, do pozostałych wystapień przymiotnika różny w obrębie kontekstów (21)-(25) możemy je dostawić (eliminując inne operatory gradacji, które w sposób naturalny się obok niego pojawiły), por.: miasto zupetnie różne od innych stolic, zapach zupełnie różny od domowego, zajac jest catkiem różny od żółwia. Taka operacja w wypadku wypowiedzeń $\mathrm{z}$ grupy (16)-(20) da połaczenia nieakceptowalne, por.: *ludzie robia zupełnie różne dziwne rzeczy, *świat jest zupelnie różny - i piękny, $i$ brzydki... itd. Innym testem, może nawet wyraźniej pokazującym różnicę pomiędzy dwiema wyodrębnionymi jednostkami, jest próba zastąienia słowa różny imiesłowem różniacy się, która - o ile pozwalaja na to wymagania składniowe zastosowanej konstrukcji - jest możliwa w zdaniach (21)-(25) (por. to miasto kontrastów, bardzo różniace się od innych stolic, znajomy zapach tortów i ciast, różniacy się od domowego), nie przechodza jej zaś pomyślnie zdania (16)-(20) (por. ludzie robia *różniace się dziwne rzeczy, *świat jest przecieź różniacy się - i piękny, i brzydki, robienie kariery $w$ *różniacy sie pokrętny sposób, $w$ tym deszczu to się *różniace się rzeczy jednak moga zdarzyc). ${ }^{12}$

Choć obie wyodrębnione jednostki są wyrażeniami predykatywnymi, różnia się od siebie pod względem znaczenia i mechanizmu przypisywania określonej właściwości. Wyrażenie różny od_, podobnie jak inny niż, implikuje istnienie choćby jednego innego elementu, $z$ którym zestawia (porównuje) się element brany pod uwage i - co istotne - w porównaniu tym zasadniczo wychodzi sie poza obręb tej samej kategorii, mamy więc do czynienia z co najmniej dwoma wyraźnie odrębnymi od siebie elementami. M. Grochowski uznaje te dwa wyrażenia za synonimiczne [Grochowski 2015, 51]. Rozwiązanie to wstępnie można przyjać, zwłaszcza że przekonuje bardziej niż teza o niedefiniowalności inny [por. Wierzbicka 1996]. Definicję obu wyrażeń dałoby się bowiem w prosty sposób skom-

12 Warto zauważyć, że zdarzają się wypowiedzenia, których nie da się w sposób jednoznaczny zinterpretować i w związu $z$ tym rozpoznać, którą $z$ dwóch wyodrębnionych jednostek reprezentują, np. Wiem, że istnieja różne religie, Jesteśmy różne, jesteśmy piękne. Wydaje się, że w przytoczonych zdaniach elementem rozstrzygającym może być kontekst. Jeśli predykat różne odnosi się do dwóch zestawianych ze soba religii lub kobiet, to $\mathrm{w}$ grę wchodziłaby jednostka różny od_ (pod względem q), czyli w rozpatrywanym wypadku różne od siebie. Jeśli zaś odnosi się on do wielu religii lub kobiet (jak zapewne jest w drugim $z$ przykładów, będącym sloganem reklamowym jednej z firm produkujących odzież dla kobiet), to chodzi prawdopodobnie o jednostkę różne (p). 
ponować z innych indefinibiliów znajdujących się na liście z 1996 roku, mianowicie wykładnika negacji nie i porównania tak(i) jak. Jej formuła dla obu wyrażeń: inny niż_i różny od_, w definiendach uwzględniających explicite element uczestniczący w porównaniu, $\mathrm{tj}$. inny niż $p$ i różny od $p$, mogłaby mieć następujacca postać: 'nie taki jak p'. Natomiast predykacja dokonywana za pomoca jednostki różne (p) opiera się na porównaniu, które dodatkowo implikuje wielość (czy też po prostu mnogość, bo ostatecznie może chyba chodzić jedynie o dwa elementy) w obrębie obiektów należących do tej samej kategorii (stąd, idacca w stronę redundancji, nieakceptowalność połączeń słowa różne z maksymalizatorem zupełnie), którą A. Bogusławski i J. Wawrzyńczyk określaja jako 'rzeczy więcej niż jednego rodzaju, które należą zasadniczo do kategorii ${ }^{13}$ [Bogusławski, Wawrzyńczyk 1993, 319], a M. Grochowski ujmuje znaczenie tego wyrażenia jako: 'X-ów należących do kategorii i jest więcej niż jeden; jest taki, który pod jakimś względem jest inny niż inny X' [Grochowski 2015, 53]. $\mathrm{Na}$ potrzeby prowadzonych badań, na tym ich etapie, jestem skłonna przyjąc takie rozwiązanie definicyjne, choć ze względu na przypadki zasygnalizowane w przypisie 12 . wydaje się, że o odróżnieniu dwóch wyodrębnionych jednostek i przyporządkowanych im znaczeń decyduje wi eloś ć elementów składających się na orzekaną cechę, z czego definicja M. Grochowskiego nie zdaje sprawy. Inna rzecz, że takie ustalenie pociaga za sobą konieczność określenia warunków rzeczonej wielości, to zaś wywołuje pytania w rodzaju: czy więcej niż dwa to już wiele i wydaje się trudne o tyle, że w grę wchodzi wartość subiektywna.

5. Przymiotnik odrębny - podobnie jak dwa opisane wyżej wyrażenia - uznany został w słownikach języka polskiego za polisemiczny (wyjątkiem jest SJPSz). O ile $z$ „wielojednostkowością" słów inny i różny (bo tak należałoby ujmować opisany problem ${ }^{14}$ ) należy się zgodzić, o tyle teza o wieloznaczności przymiotnika odrębny jest dyskusyjna. W drugim $z$ wyodrębnionych znaczeń (por. fragment w p. 2. poświęcony ujęciom leksykograficznym wyrażenia odrębny) zwraca się uwagę na granice stanowiące o istnieniu określonego bytu będącego samodzielna całościa, np. odrębny teren dla dzieci [ISJP], odrębne zaplecze kuchenne [USJP], ale też odrębne zagadnienie, odrębne kwestie [SWJP], podczas gdy w pierwszym do roli dystynkcji podnosi się różnicę wyeksponowana w niektórych opisach [np. w ISJP, SWJP i PSWP] poprzez jej zintensyfikowanie operatorami bardzo, zupetnie lub znacznie (por. odpowiednio: 'bardzo różny', 'zupełnie inny, różny od innych', 'znacznie różni się od in-

13 Taka samą definicję autorzy drugiej sondy słownikowej zaproponowali dla wyrażenia rozmaity (ściślej: rozmaite $\operatorname{coś}_{-}^{-}$[por. Bogusławski, Wawrzyńczyk 1993, 314], co pozwala stwierdzić, że uznali te dwie jednostki za synonimiczne.

14 Por. na ten temat artykuł Magdaleny Danielewiczowej [2011] Wieloznaczność - skaza na języku czy na jego opisie? 
nych'). Tymczasem konteksty występowania wyrażenia odrębny takiego zróżnicowania według mnie nie pokazują:

(26) To stanowi odrębny problem.

(27) Zagadnieniom tym poświęcam odrębny rozdział 9.

(28) To odrębny gatunek muzyczny.

(29) Nadanie imienia stwarza przedmiot jako odrębny byt, nobilituje go do rangi jednostkowego.

(30) Obiekty moga stanowić odrębny element.

(31) Wiadomo powszechnie, że każdego pisarza cechuje odrębny styl.

Nie pokazuja go raczej także przykłady słownikowe ilustrujące użycie rozpatrywanego wyrażenia w dwóch suponowanych znaczeniach, por. np. odrębne zagadnienie jako przykład znaczenia drugiego. Jeśliby już mówić o różnicy znaczeń, to trzeba by opierać ja - jak w ISJP [I, 538] - na opozycji abstrakt - konkret, por. odrębny sposób myślenia vs odrębny teren dla dzieci [ISJP]. W pierwszym wypadku przymiotnik odrębny określałby byty będące rezultatami czyjejś aktywności mentalnej, w drugim - byty konkretne, zwykle mające charakter przestrzenny, których granice sa spostrzegalne za pomoca zmysłów (można je np. zobaczyć). Tyle że znaczenia te sa według mnie sprowadzalne do jednego: niezależnie od odniesienia wyrażenia określanego przez przymiotnik odrębny cecha ta zawsze ma charakter, powiedzmy, ontologiczny. To, czemu przypisujemy własność odrębności, jest inne od innych bytów i to, że różni się od nich, warunkuje jego istnienie. Orzekanie odrębności czegoś jest $\mathrm{w}$ istocie równoważne $\mathrm{z}$ istnieniem tego, istnienie czegoś $z$ kolei implikuje granice tego czegoś. To zaś, czy sa one percypowalne i mierzalne fizycznie, czy też rozpoznaje się je w inny sposób (mentalnie), jest kwestią drugorzędna, jeśli nie marginalna. Dlatego tezę o wieloznaczności wyrażenia odrębny uważam za niesłuszna. Co do postaci jednostki językowej reprezentującej pojęcie odrębności, to ze względu na możliwość uzupełnienia przymiotnika odrębny przyimkiem od (jak np. w zdaniach Kiedyś uważano neandertalczyka za odrębny od naszego, dziki, prymitywny gatunek przedludzki, Tak zwani fizyczni maja odrębny od inteligenckiego pośredniak) można by przystać na zapis odrębny (od_) z fakultatywna fraza przyimkową-rzeczownikową.

6. Stosunkowo najmniej wymagajacy w opisie jest przymiotnik odmienny. Pomijając oczywiste jego funkcjonowanie jako terminu językoznawczego oraz przestarzałe jego użycia w rodzaju odnotowywanego w słownikach połaczenia odmienne koleje losu (por. przypis 6.), trzeba by mówić o jednej jednostce reprezentującej pojęcie odmienności i odpowiadającym jej jednym znaczeniu. Słowo odmienny występuje $z$ uzupełniającym je przyimkiem od lub niż i następująca po nim fraza nominalna (por. niżej (32)-(35)). Nawet jeśli tego elementu nie ma na powierzchni zdania, jest on składnikiem presuponowanym, co istotne - bardzo często semantycznie (por. niżej w przykładach (36)-(38) wyrażenia oboje, obu oraz wykładnik referencji dystrybutywnej każdy implikujące istnie- 
nie zbioru), a nie pragmatycznie (kontekstowo) (por. niżej przykłady (39) i (40), w których dopiero $z$ uzupełnienia idącego po rozpatrywanej predykacji dowiadujemy się o zasadności orzekania odmienności o tonie czyjejś wypowiedzi czy o wyglądzie czyjegoś dworu, czyli o możliwości charakterystyki tej cechy poprzez zestawienie ze sobą dwóch skrajnie innych elementów). Por. przykładowe konteksty:

(32) Był obcy, a zarazem całkowicie odmienny od mężczyzn, których widywała na ulicach Kopenhagi.

(33) Dwie kobiety wyznaja sobie miłość w odmienny sposób niż dwaj mężczyźni.

(34) Zdecydowali się także na odmienny od tradycyjnego kształt maszyny.

(35) Druga część książki jest odmienna od pozostałych.

(36) Oboje przeczuwali wojnę, ale w odmienny sposób.

(37) W każdym horoskopie jest odmienny układ planet.

(38) Jednak świat penetrowany przez obu artystów był odmienny.

(39) Gross wprowadza odmienny ton. Mówi ostro, bezpośrednio, ironicznie.

(40) Dwór Moniaków przybrał już odmienny wyglad, dzięki pokryciu dachu słoma.

W związku $z$ powyższym należałoby postulować postać jednostki odmienny od_ (pod względem q) uzupełniona, niefakultatywnie tym razem (inaczej niż w wypadku wyrażenia odrębny), o prawostronny składnik denotujacy element wchodzacy w porównanie $z$ innym elementem (denotowanym przez wyrażenie zwykle umieszczone wcześniej na linii zdania).

7. Zgodnie $z$ ustaleniami dokonanymi w poszczególnych częściach tej analizy postuluje wyodrębnienie trzech jednostek języka reprezentujących pojęcie inności: predykatywnej inny niż_ (pod względem q), referencjalnej inny i referencjalnej o charakterze operacyjnym_inny, dwóch jednostek reprezentujących pojęcie różności: różny od_ (pod względem q) i różne (p), i po jednej jednostce reprezentującej pojęcia odrębności i odmienności: odpowiednio odrębny (od_)i odmienny od_(pod względem q). Porównywalne ze soba sa jednostki inny niż_ (pod względem q), różny od_ (pod względem q), odrębny (od_) i odmienny od_(pod względem q). Powinny one stanowić przedmiot dalszych badań zmierzajacych w kierunku charakterystyki ich znaczenia. W pierwszej kolejności należałoby poddać systematycznej analizie kwestię ich łączliwości i wskazać ewentualne ograniczenia selekcyjne w jej obrębie. Najbardziej liberalne pod tym względem wydaja się wyrażenia inny niż_ (pod względem q) i różny od_ (pod względem q), wchodzacce w połączenia $z$ nazwami bytów i konkretnych, i abstrakcyjnych (por. przytoczone w p. 3. i p. 4. przykłady $z$ tymi predykatami). W obrębie połączeń, w jakie wchodza jednostki odrębny (od_) i odmienny od_(pod względem q), da się wprawdzie wskazać kolokacje najczęstsze i najbardziej dla nich charakterystyczne, ale trudno ze stuprocentowa pewnością wykluczyć inne. I tak odrębny (od_) 
zwykle określa wyrażenia nazywające byty abstrakcyjne, np. odrębny byt / element / problem / temat / styl / gatunek, bywa też jednak określeniem nazw konkretnych, zwłaszcza nazw przestrzeni - zarówno zamkniętych (odrębne pomieszczenie, odrębny pokój), jak i otwartych (odrębny teren, odrębna działka). $Z$ nazwami właściwości abstrakcyjnych łączy się również jednostka odmienny od_ (pod względem q) (np. odmienne poglady, odmienny charakter, odmienny punkt widzenia), jednak odmienność orzeka się także o sposobie wykonywania czynności, o cechach ludzi i istot w ogóle, a także o ich wyglądzie (np. odmienny od tradycyjnego kształt maszyny, dwór Moniaków przybrał odmienny wygląd). Kontrowersyjność niektórych połączeń rozpatrywanych jako wyrażenia izolowane często odpiera kontekst, por. np. budzace wątpliwości frazy ?odmienne kartki, ?odrębne kartki, które w kontekście całego zdania (uwzględniającego ich właściwości walencyjne), a najlepiej wypowiedzi (osadzonej w określonej sytuacji komunikacyjnej), się bronią, np. ta kartka jest odmienna od tej (kartki), ta kartka jest odrębna (od tej) kartka (o fragmencie papieru oderwanym od innego kawałka papieru). Pomimo trudności ze wskazaniem połączeń, których badane wyrażenia bezdyskusyjnie nie realizuja, daja się sformułować pewne przypuszczenia na temat ich właściwości semantycznych. Inny niż_ (pod względem q) wchodzi prawdopodobnie w relację synonimii $z$ jednostką różny od_ (pod względem q) (choć próby wzajemnej substytucji, zwłaszcza innego niż_ (pod względem q) przez różnego od_ (pod względem q), wymagaja zmian struktury powierzchniowej zdania) i w relację hiponimii $z$ wyrażeniami odrębny (od_) i odmienny od_(pod wzgledem q). Inny niż_ (pod względem q) trzeba traktować jako hiperonim dwóch ostatnich jednostek, w których znaczeniu oprócz elementów wspólnych $z$ innym należałoby poszukać komponentu (lub komponentów) dystynktywnego (dystynktywnych), odróżniającego (odróżniających) go od tego wyrażenia. Dla 'odrębności' znamienna wydaje się ontologiczność - $\cos _{\mathrm{x}}$ jest inne od czegoś ${ }_{\mathrm{y}}$ i $z$ tego powodu można o czymśs $\hat{x}_{\mathrm{x}}$ powiedzieć, że jest (istnieje). 'Odmienność' zdaje się odróżniać od pojęć pokrewnych dwubiegunowością czy kontrastowościa elementów zestawianych ze sobą pod względem określonej cechy - $\cos _{x}, c_{x}$ jest odmienne od czegoś ${ }_{y}$, jest skrajnie inne od tego . Sa to oczywiście jedynie bardzo robocze, intuicyjnie wysunięte postulaty semantyczne, wymagające sprecyzowania i sprawdzenia (poddania ich próbie sfalsyfikowania). Jest to jednak zadanie na przyszłość. Podobnie jak powrót do poruszonego w tych rozważaniach problemu niedefiniowalności wyrażenia inny (por. p. 4.) czy rozważenie interpretacji 'inności' w ujęciu m.in. G.W. Leibniza (por. przypisy 1. i 2.). 


\section{Bibliografia}

A. Bogusławski, 1976, O zasadach rejestracji jednostek języka, „Poradnik Językowy" z. 8, s. 356-364.

A. Bogusławski, M. Danielewiczowa, 2005, Verba polona abscondita. Sonda słownikowa III, Warszawa.

A. Bogusławski, J. Wawrzyńczyk, 1993, Polszczyzna, jaka znamy. Nowa sonda słownikowa, Warszawa.

M. Danielewiczowa, 2011, Wieloznaczność - skaza na języku czy na jego opisie? [w:] Różne formy, różne treści. Tom ofiarowany Profesorowi Markowi Świdzińskiemu, red. M. Bańko, D. Kopcińska, Warszawa, s. 37-47.

M. Grochowski, 2015, Jednostka najróżniejsze na tle operacji semantycznej stopniowania, „LingVaria” X, nr specjalny, s. 47-60.

M. Grochowski, 2016, Poszczególne wśród operatorów kwantyfikacji, „LingVaria” XI, 2 (22), s. 83-95.

M. Grochowski, 2017, Wybór i nieokreśloność jako komponenty semantyczne przymiotnika dowolny, „Annales Universitatis Paedagogicae Cracoviensis. Studia Linguistica" XII, s. 104-111.

M. Grochowski, 2018, Asymetria semantycznych i gramatycznych ograniczeń stopniowania przymiotników w języku polskim [w:] Z Polskich Studiów Slawistycznych, seria 13, t. 2, s. 85-94.

ISJP: M. Bańko (red.), 2000, Inny słownik języka polskiego, t. I-II, Warszawa.

G.W. Leibniz, 1975, Tablice definicji [Tabulae definitionum] [w:] E. Janus (red.), Slownik $i$ semantyka. Definicje semantyczne, Wrocław, s. 8-89.

PSWP: H. Zgółkowa (red.), 1994-2005, Praktyczny słownik współczesnej polszczyzny, t. I-L, Poznań.

SJPSz: M. Szymczak (red.), 1988-1989, Stownik języka polskiego, t. I-III, Warszawa.

SWJP: B. Dunaj (red.), 1996, Słownik współczesnego języka polskiego, Warszawa.

Z. Topolińska, 1983, Składnia grupy imiennej [w:] Z. Topolińska (red.), Gramatyka współczesnego języka polskiego. Składnia, Warszawa, s. 301-386.

USJP: S. Dubisz (red.), 2003, Uniwersalny słownik języka polskiego, t. I-V, Warszawa.

A. Wierzbicka, 1996, Semantics. Primes and Universals, Oxford-New York.

A. Wierzbicka, 2006, Semantyka. Jednostki elementarne i uniwersalne, Lublin.

\section{Other, different, distinct, dissimilar. An attempt at identifying linguistic units}

\section{Summary}

The aim of this paper is to identify linguistic units which represent the notions of inność, różność, odrębność and odmienność (otherness, difference, distinctiveness and dissimilarity). The outcome of the examination provides data which are indispensable in further systematic analysis of their meanings. Determining the number of linguistic units corresponding to a given term as 
well as describing their forms give insight into the syntactic properties of the identified units (which can become premises for strictly semantic conclusions). Detailed descriptions of the lexical exponents of all four terms are based on authentic textual instances of their usage (taken from the National Corpus of Polish). Observations which originated from the undertaken analysis are confronted with the findings presented in dictionaries of contemporary Polish. The solutions proposed in this paper, although they refer to semantics, virtually fail to go beyond the issues related to the problem of identifying linguistic units.

Adj. Monika Czarnecka 